\title{
Evaluation of heavy metal mobility in contaminated soils between Abu Qurqas and Dyer Mawas Area, El Minya Governorate, Upper Egypt
}

\author{
Ahmed S. A. Asmoay ${ }^{1 *}$ (D), Salman A. Salman ${ }^{1}$, Amr M. El-Gohary ${ }^{1}$ and Hassan S. Sabet ${ }^{2}$
}

\begin{abstract}
Background: Heavy metals have dangerous effect on the biota. So, this work aimed to determine the mobility and bioavailability of these metals through the application of pollution indices and geochemical fractionation technique. Thirty-one topsoil samples $(20 \mathrm{~cm})$ were collected from the area between Abu Qurqas and Dyer Mawas, El Minya Governorate, and subjected to chemical analysis.

Results: The results revealed that $\mathrm{Cd}$ and $\mathrm{As}$ are mainly associated with carbonate fraction while $\mathrm{Cr}, \mathrm{Pb}, \mathrm{Ni}$, and $\mathrm{Cu}$ are more present in the residual fraction. The relative amounts of easily dissolved phase of heavy metals in the soils are in the order of $\mathrm{As}>\mathrm{Cd}>\mathrm{Cr}>\mathrm{Pb}>\mathrm{Ni}>\mathrm{Cu}$.

Conclusion: The results revealed that $\mathrm{As}, \mathrm{Cd}$, and $\mathrm{Cr}$ have high mobility and risks more than $\mathrm{Pb}, \mathrm{Ni}$, and $\mathrm{Cu}$ metals in the studied soils. As, $\mathrm{Cd}$, and $\mathrm{Cr}$ were the heavy metals that caused pollutants in the soils of the studied area.
\end{abstract}

Keywords: Soil, Heavy metals, Pollution, Contaminants, Speciation, Sequential extraction, Mobility, Risk

\section{Introduction}

Metal contamination of soil is an important concern to human and environmental health worldwide. The potential toxicity of heavy metals in soil is a function of their mobility and bioavailability. Metal mobility is depending on the phase in which the metal occurs as well as physical and chemical processes that control transformations between phases. Some heavy metals cause damage to the nervous system and internal organs as well as carcinogenic effects (Lee et al. 2007; Maas et al. 2010). One of the most critical properties of these metals that distinguish them from other contaminants is their persistence and non-biodegradability in the environment (Ghaderi et al. 2012; Yang et al. 2012).

Heavy metals in soils are derived from natural sources such as weathering of rock, volcanoes, and forest fires as well as anthropogenic activities such as the industrial

\footnotetext{
* Correspondence: asmoay@gmail.com

${ }^{1}$ Geological Sciences Department, National Research Centre, 33 El Bohouth

St. (former El Tahrir St.)-Dokki, Giza 12622, Egypt

Full list of author information is available at the end of the article
}

effluent, fertilizers, atmospheric deposition, traffic, agricultural drainage, and phosphate industry (Ghaderi et al. 2012; Wali et al. 2013).

Several studies have estimated the total metal contents in polluted and unpolluted soils (Vega et al. 2004; Covelo et al. 2007; Kierczak et al. 2008; Maas et al. 2010; Nemati et al. 2011; Wali et al. 2013, Mohamed et al. 2015, Elnazer et al. 2015; Salman et al. 2016; Salman et al. 2018; Said et al. 2019). However, the total contents of trace metals cannot give enough information about their various forms, mobility, bioavailability, or potential risks to the environment (Davutluoglu et al. 2011; Nemati et al. 2011). In contrast, the speciation analysis for metals in soil can give a good indicator of the ecosystem quality. Metals may be present in soil in several physicochemical phases, including soluble or exchangeable, bound to amorphous material (Fe/Mn oxides), bound to organic matter, sulfides, and bound to mineral fractions (residual) (Rauret et al. 1999; Zemberyova et al. 2006; Perez-Lopez et al. 2010 and Nemati et al. 2011). The mobility and bioavailability of trace metals are highly 


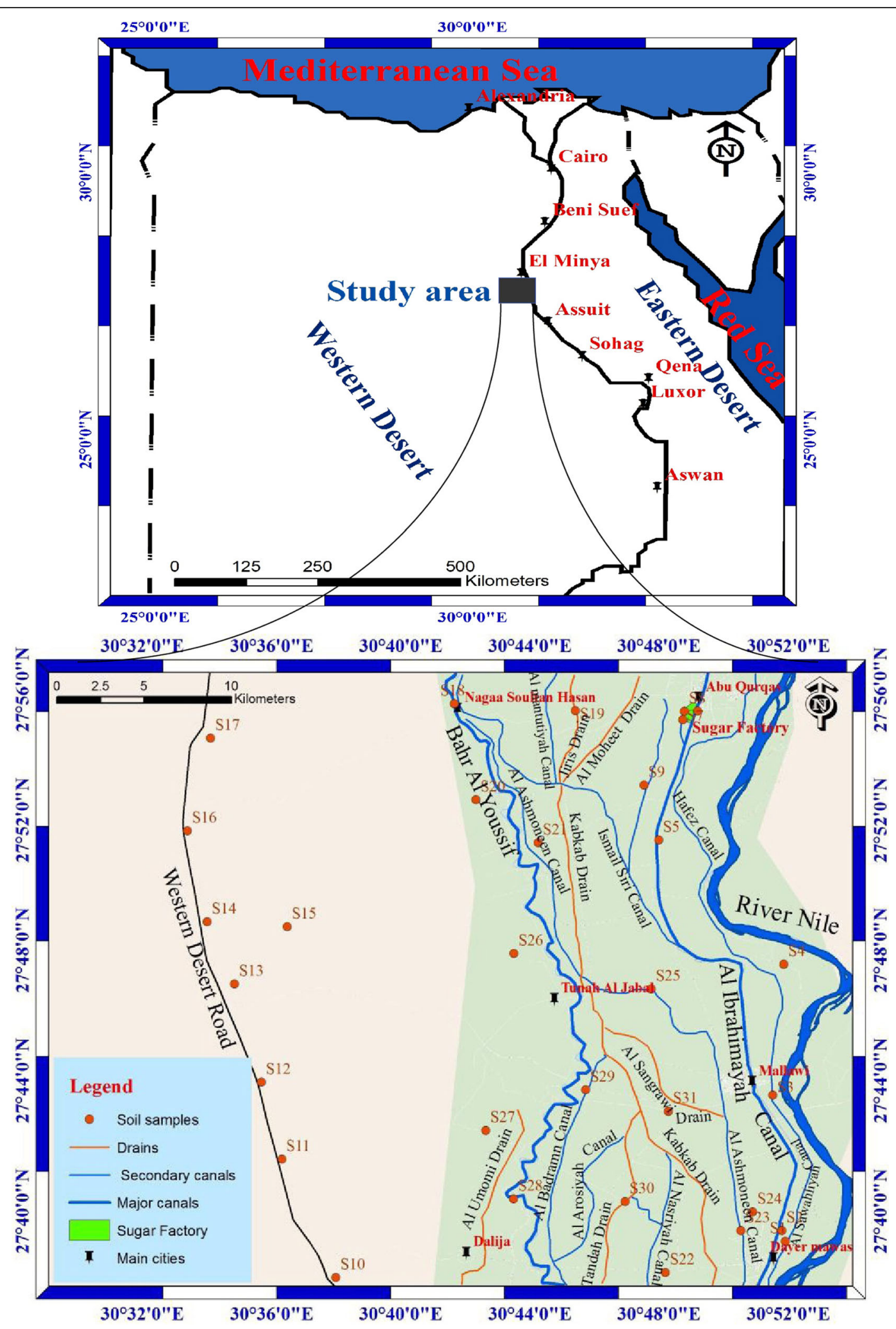

Fig. 1 Location map of the study area and sampling sites 


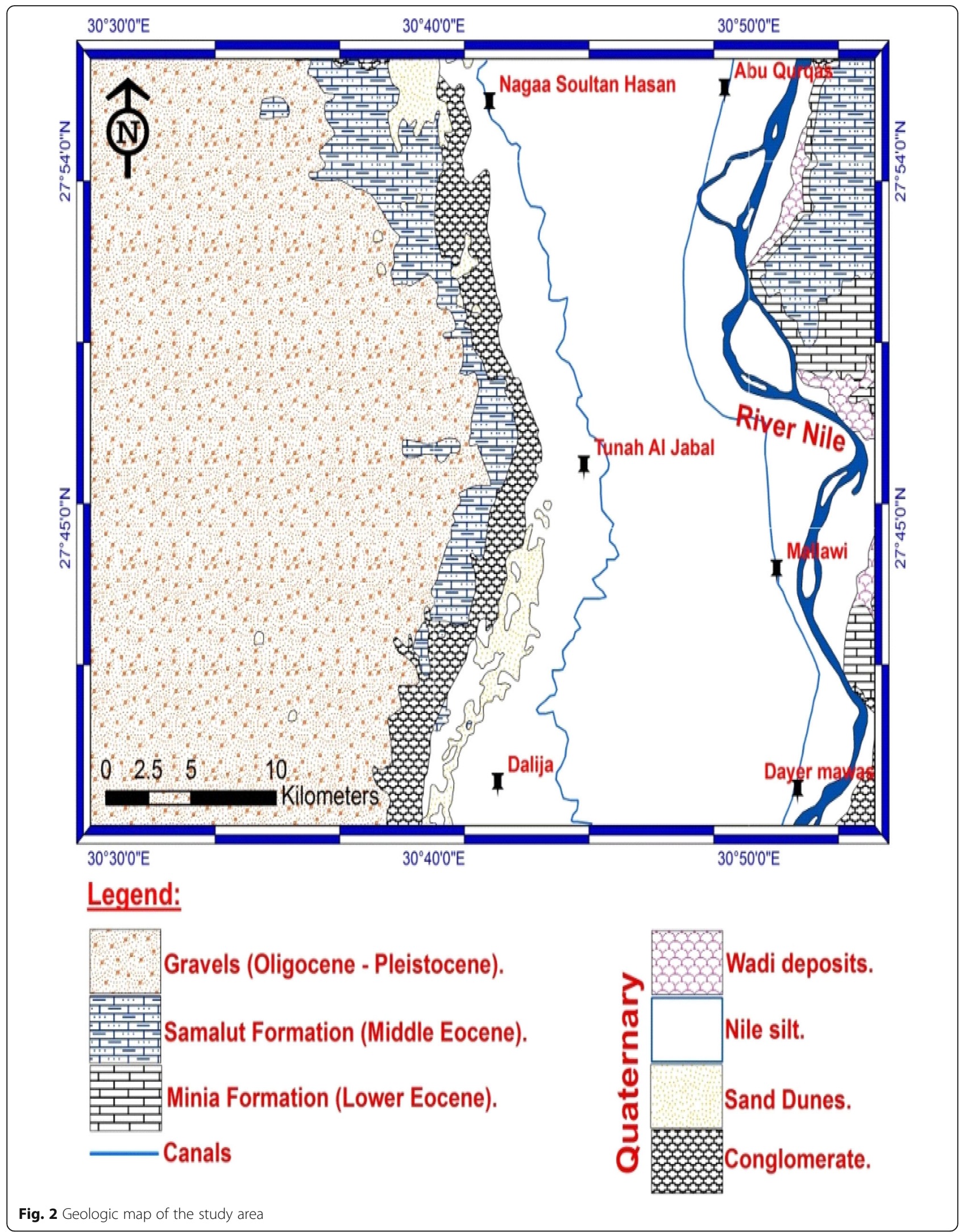


dependent on their specific chemical forms or behavior of binding to each soil phase. Sequential extraction procedures have recently been developed to detect the speciation of heavy metals in soil matrix; these procedures provide more information on the origin, physicochemical availabilities, mobilization, and transport of trace metals in natural environments (Kierczak et al. 2008; Rao et al. 2010; Nemati et al. 2011; Aiju et al. 2012).

In case of plants, free metal ions in the soil solution may be more toxic than metals in the complex states (Gupta and Sinha 2006). Accordingly, only the labile metal species (soluble, exchangeable, and chelated) are available to plants. Thus, the detection of total concentrations must be complemented by evaluating available fractions of metals (Buccolieri et al. 2010). The specific objective of this work was the determination of the mobility and bioavailability of heavy metals (As, $\mathrm{Cd}, \mathrm{Cr}, \mathrm{Pb}, \mathrm{Ni}$, and $\mathrm{Cu}$ ) through the application of pollution indices and geochemical fractionation technique.

\section{Location}

The study area occupied the middle part of the Nile Valley between longitudes $30^{\circ} 29^{\prime}$ and $30^{\circ} 54^{\prime} \mathrm{E}$ and latitudes $27^{\circ} 37^{\prime}$ and $27^{\circ} 56^{\prime} \mathrm{N}$ (Fig. 1) between Abu Qurqas and Dyer Mawas Area, El Minya Governorate. The stratigraphic succession in El Minya Area is represented by Tertiary and Quaternary sedimentary rocks. The distribution of the different rock units was indicated in Said (1981). The stratigraphic sequence is built up from base to top as follows: Middle Eocene limestone intercalated with shale (Samalut Formation); Pliocene undifferentiated sands, clays, and conglomerates; Plio-Pleistocene sand and gravel with clay and

Table 1 Classification of enrichment factor (EF) and geoaccumulation indices $\left(\mathrm{I}_{\text {geo }}\right)$

\begin{tabular}{|c|c|c|}
\hline \multicolumn{2}{|c|}{ EF values } & Class of EF \\
\hline \multicolumn{2}{|l|}{$<2$} & Depletion to minimal enrichment \\
\hline \multicolumn{2}{|l|}{$2-5$} & Moderate enrichment \\
\hline \multicolumn{2}{|l|}{$5-20$} & Significant enrichment \\
\hline \multicolumn{2}{|c|}{$20-40$} & Very high enrichment \\
\hline \multicolumn{2}{|l|}{$>40$} & Extremely high enrichment \\
\hline Grade & $I_{\text {geo }}$ values & Soil quality \\
\hline 0 & $<0$ & Practically unpolluted \\
\hline 1 & $0-1$ & Unpolluted to moderately polluted \\
\hline 2 & $1-2$ & Moderately polluted \\
\hline 3 & $2-3$ & Moderately polluted to heavily polluted \\
\hline 4 & $3-4$ & Heavily polluted \\
\hline 5 & $4-5$ & Heavily polluted to extremely polluted \\
\hline 6 & $>5$ & Extremely polluted \\
\hline
\end{tabular}

Table 2 Heavy metal content in the studied soil samples (ppm)

\begin{tabular}{lllllll}
\hline Sample no. & $\mathrm{Cd}$ & $\mathrm{As}$ & $\mathrm{Cr}$ & $\mathrm{Pb}$ & $\mathrm{Ni}$ & $\mathrm{Cu}$ \\
\hline Min. & 0.35 & $\mathrm{ND}$ & 89 & $\mathrm{ND}$ & 18 & 35 \\
Max. & 2.60 & 140 & 260 & 300 & 170 & 140 \\
Mean & 1.19 & 27 & 182 & 54 & 111 & 92 \\
MAC & $1-5$ & $1-10$ & $50-200$ & $20-300$ & $20-60$ & $60-150$
\end{tabular}

ND not detected, MAC maximum allowable concentration (after Kabata-

Pendias and Mukherjee 2007)

Table 3 Enrichment factor (EF) and geoaccumulation index $\left(I_{\text {geo }}\right)$ of heavy metals in soil samples

\begin{tabular}{|c|c|c|c|c|c|c|c|c|c|c|}
\hline \multirow[b]{2}{*}{$\begin{array}{l}\text { Sample } \\
\text { no. }\end{array}$} & \multicolumn{5}{|l|}{ EF } & \multicolumn{5}{|l|}{$I_{\text {geo }}$} \\
\hline & As & $\mathrm{Cr}$ & $\mathrm{Pb}$ & $\mathrm{Ni}$ & $\mathrm{Cu}$ & As & $\mathrm{Cr}$ & $\mathrm{Pb}$ & $\mathrm{Ni}$ & $\mathrm{Cu}$ \\
\hline$S_{1}$ & 16.53 & 2.60 & 9.92 & 5.26 & 5.97 & 3.74 & 1.07 & 3.00 & 2.08 & 2.27 \\
\hline$S_{2}$ & 0.00 & 3.76 & 0.00 & 4.26 & 5.20 & - & 1.68 & - & 1.86 & 2.15 \\
\hline$S_{3}$ & 1.56 & 2.60 & 2.19 & 4.61 & 5.64 & 0.42 & 1.15 & 0.90 & 1.98 & 2.27 \\
\hline $\mathrm{S}_{4}$ & 0.85 & 3.01 & 1.60 & 4.71 & 3.86 & -0.39 & 1.44 & 0.53 & 2.08 & 1.80 \\
\hline $\mathrm{S}_{5}$ & 1.12 & 2.75 & 0.97 & 4.26 & 4.16 & -0.07 & 1.23 & -0.27 & 1.86 & 1.83 \\
\hline $\mathrm{S}_{6}$ & 1.44 & 2.54 & 1.59 & 4.59 & 4.00 & 0.42 & 1.23 & 0.55 & 2.08 & 1.89 \\
\hline$S_{7}$ & 5.51 & 2.97 & 3.53 & 5.11 & 6.24 & 2.19 & 1.30 & 1.55 & 2.08 & 2.37 \\
\hline $\mathrm{S}_{8}$ & 3.54 & 3.21 & 2.12 & 5.26 & 6.43 & 1.51 & 1.37 & 0.77 & 2.08 & 2.37 \\
\hline $\mathrm{S}_{9}$ & 3.46 & 2.75 & 2.47 & 5.32 & 4.34 & 1.56 & 1.23 & 1.07 & 2.18 & 1.89 \\
\hline$S_{10}$ & 0.24 & 0.20 & 0.00 & 0.28 & 0.23 & 0.86 & 0.57 & - & 1.06 & 0.83 \\
\hline$S_{11}$ & 0.32 & 0.16 & 0.13 & 0.18 & 0.22 & 1.82 & 0.79 & 0.50 & 0.98 & 1.31 \\
\hline$S_{12}$ & 0.19 & 0.20 & 0.09 & 0.19 & 0.20 & 0.86 & 0.98 & -0.14 & 0.89 & 0.95 \\
\hline$S_{13}$ & 0.17 & 0.14 & 0.04 & 0.17 & 0.10 & 1.65 & 1.37 & -0.42 & 1.60 & 0.89 \\
\hline$S_{14}$ & 0.00 & 0.30 & 0.00 & 0.38 & 0.35 & - & 0.57 & - & 0.93 & 0.80 \\
\hline$S_{15}$ & 0.14 & 0.13 & 0.09 & 0.12 & 0.12 & 1.07 & 0.98 & 0.42 & 0.91 & 0.92 \\
\hline$S_{16}$ & 0.00 & 0.31 & 0.00 & 0.36 & 0.20 & - & 0.98 & - & 1.22 & 0.37 \\
\hline $\mathrm{S}_{17}$ & 0.43 & 0.24 & 0.26 & 0.30 & 0.36 & 1.31 & 0.44 & 0.58 & 0.79 & 1.03 \\
\hline$S_{18}$ & 0.00 & 2.73 & 0.00 & 3.95 & 5.20 & - & 1.44 & - & 1.98 & 2.37 \\
\hline$S_{19}$ & 1.95 & 2.68 & 0.96 & 4.74 & 4.46 & 0.70 & 1.15 & -0.32 & 1.98 & 1.89 \\
\hline$S_{20}$ & 3.79 & 2.75 & 2.97 & 4.61 & 4.12 & 1.70 & 1.23 & 1.34 & 1.98 & 1.81 \\
\hline$S_{21}$ & 0.00 & 3.04 & 0.00 & 4.61 & 4.34 & - & 1.37 & - & 1.98 & 1.89 \\
\hline $\mathrm{S}_{22}$ & 2.36 & 2.75 & 0.93 & 4.51 & 5.97 & 0.93 & 1.15 & -0.42 & 2.18 & 2.27 \\
\hline$S_{23}$ & 3.44 & 2.97 & 1.99 & 5.47 & 4.91 & 1.51 & 1.30 & 0.73 & 2.08 & 2.03 \\
\hline$S_{24}$ & 1.69 & 2.60 & 0.80 & 4.71 & 4.11 & 0.61 & 1.23 & -0.47 & 2.36 & 1.89 \\
\hline $\mathrm{S}_{25}$ & 4.37 & 3.21 & 2.48 & 6.39 & 4.59 & 1.82 & 1.37 & 1.00 & 1.51 & 1.89 \\
\hline $\mathrm{S}_{26}$ & 0.08 & 0.11 & 0.08 & 0.12 & 0.07 & 0.93 & 1.44 & 0.86 & 1.74 & 0.83 \\
\hline$S_{27}$ & 0.31 & 0.17 & 0.18 & 0.52 & 0.25 & 1.00 & 0.14 & 0.20 & -0.87 & 0.70 \\
\hline $\mathrm{S}_{28}$ & 0.96 & 2.23 & 0.48 & 0.55 & 4.09 & -0.07 & 1.15 & -1.06 & 1.86 & 2.03 \\
\hline $\mathrm{S}_{29}$ & 0.00 & 2.95 & 0.00 & 4.14 & 3.80 & - & 1.37 & - & 1.86 & 1.74 \\
\hline$S_{30}$ & 2.75 & 2.82 & 0.90 & 4.38 & 5.80 & 1.19 & 1.23 & -0.42 & 2.08 & 2.27 \\
\hline$S_{31}$ & 10.27 & 2.91 & 1.92 & 5.26 & 4.32 & 3.05 & 1.23 & 0.63 & 2.18 & 1.80 \\
\hline Average & 2.18 & 1.99 & 1.25 & 3.20 & 3.34 & - & - & - & - & - \\
\hline
\end{tabular}


Table 4 Cadmium fractionation results (ppm)

\begin{tabular}{llllll}
\hline Samples & Ex & $\mathrm{Ct}$ & $\mathrm{Ob}$ & $\mathrm{FM}$ & $\mathrm{Rd}$ \\
\hline $\mathrm{S}_{1}$ & 0.08 & 1.63 & 0.25 & 0.21 & 0.38 \\
$\mathrm{~S}_{7}$ & 0.08 & 0.96 & 0.32 & 0.28 & 0.36 \\
$\mathrm{~S}_{8}$ & 0.18 & 0.62 & 0.31 & 0.22 & 0.53 \\
$\mathrm{~S}_{9}$ & 0.05 & 0.69 & 0.14 & 0.09 & 0.19 \\
$\mathrm{~S}_{25}$ & 0.04 & 0.65 & 0.12 & 0.07 & 0.11 \\
$\mathrm{~S}_{31}$ & 0.03 & 0.45 & 0.19 & $\mathrm{ND}$ & 0.13 \\
Mean & 0.08 & 0.83 & 0.22 & 0.14 & 0.28 \\
\hline
\end{tabular}

Ex exchangeable fraction, $C t$ carbonate-bound fraction, $\mathrm{Ob}$ organic matterbound fraction, FM Fe-Mn oxide-bound fraction, $R d$ residual fraction

shale lenses; Pleistocene sand and gravel with clay lenses; and Holocene silt and clay (Fig. 2); the main economy of the study area is based on agricultural and agro-industrial activities. The cultivated areas are represented by two plains, the older alluvial plain (reclaimed land) and the younger alluvial plain (agriculture soil) which originated from the Ethiopian Plateau (Abd Elsanad 2010).

\section{Material and methods}

In November 2014, 31 surface soil samples $(20 \mathrm{~cm})$ have been collected from the study area (Fig. 1); the samples were air-dried, crushed, passed through a 2$\mathrm{mm}$ sieve, and stored at ambient temperature. Afterwards, the coning and quartering method was used to obtain representative sub-samples; each quarter was thoroughly homogenized, and about $50 \mathrm{~g}$ was milled to a diameter of $<0.01 \mathrm{~mm}$ and another $50 \mathrm{~g}$ to a diameter of $<63 \mu \mathrm{m}$ for further analysis. Afterwards, $1 \mathrm{~g}$ of soil was digested with aqua regia $\left(3: 1 \quad \mathrm{HCl}: \mathrm{HNO}_{3}\right)$ and analyzed for heavy metals. Enrichment factor (EF) was used to assess the accumulation or leaching processes of heavy metals in soils for the detection of their behaviors. It may be determined by comparing concentrations of certain heavy metal with a reference element (Kabata-Pendias and Pendias 2001). This factor has been calculated from the following equation according to Buat-Menerd and Chesselt (1979). According to the equation, $\mathrm{EF}=\left(E_{\mathrm{s}} / E_{\text {background }}\right) /\left(R_{\mathrm{s}} / R_{\text {background }}\right)$, where $E_{\mathrm{s}}$ is the content of the element in the soil, $E_{\text {background }}$ is the content of the same element in soils worldwide, $R_{\mathrm{s}}$

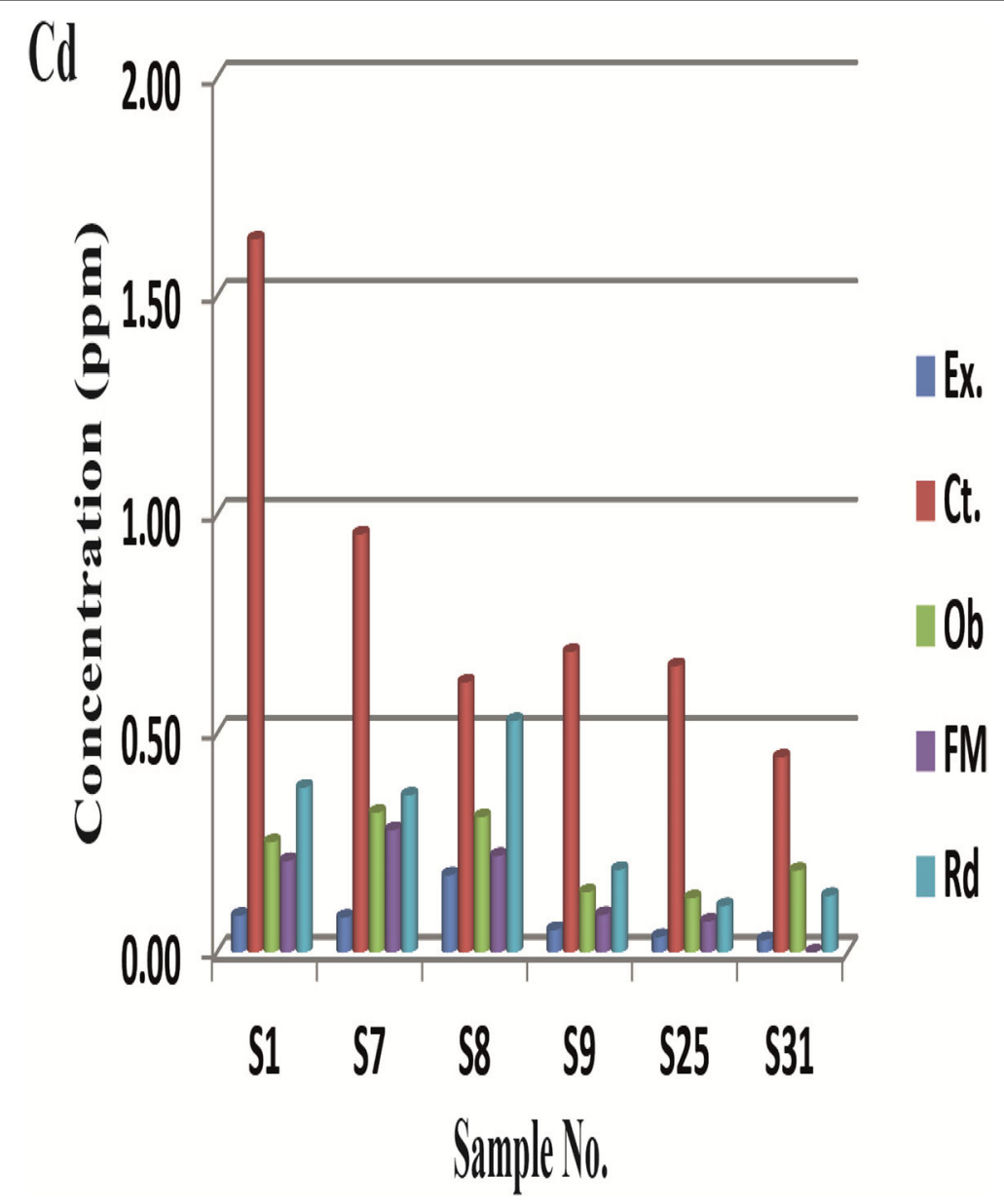

Fig. 3 Distribution of $\mathrm{Cd}$ among the various soil fractions in the study area 
Table 5 Arsenic fractionation results (ppm)

\begin{tabular}{llllll}
\hline Samples & Ex & $\mathrm{Ct}$ & $\mathrm{Ob}$ & $\mathrm{FM}$ & $\mathrm{Rd}$ \\
\hline $\mathrm{S}_{1}$ & $\mathrm{ND}$ & 126 & $\mathrm{ND}$ & $\mathrm{ND}$ & $\mathrm{ND}$ \\
$\mathrm{S}_{7}$ & $\mathrm{ND}$ & 43.20 & $\mathrm{ND}$ & $\mathrm{ND}$ & $\mathrm{ND}$ \\
$\mathrm{S}_{8}$ & $\mathrm{ND}$ & 27 & $\mathrm{ND}$ & $\mathrm{ND}$ & $\mathrm{ND}$ \\
$\mathrm{S}_{9}$ & $\mathrm{ND}$ & 27.90 & $\mathrm{ND}$ & $\mathrm{ND}$ & $\mathrm{ND}$ \\
$\mathrm{S}_{25}$ & $\mathrm{ND}$ & 33.30 & $\mathrm{ND}$ & $\mathrm{ND}$ & $\mathrm{ND}$ \\
$\mathrm{S}_{31}$ & $\mathrm{ND}$ & 78.30 & $\mathrm{ND}$ & $\mathrm{ND}$ & $\mathrm{ND}$ \\
Mean & $\mathrm{ND}$ & 55.95 & $\mathrm{ND}$ & $\mathrm{ND}$ & $\mathrm{ND}$ \\
\hline
\end{tabular}

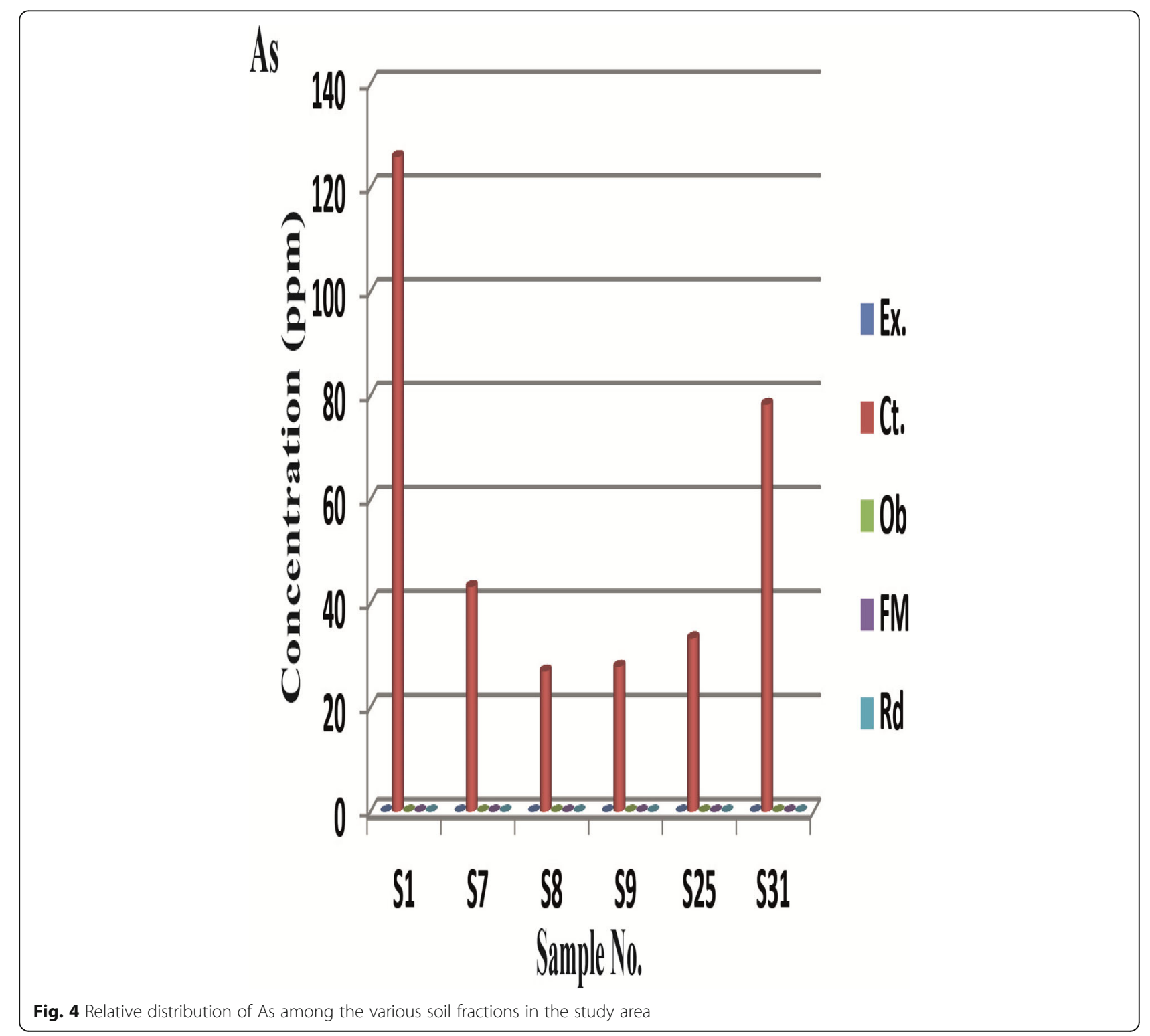

is the content of the reference metal in the soil, and $R_{\text {background }}$ is the content of the same reference element in soils worldwide.

Geoaccumulation $\left(\mathrm{I}_{\text {geo }}\right)$ index was applied to assess the pollution of metals in the soil. The geoaccumulation index $\left(\mathrm{I}_{\text {geo }}\right)$ is defined by the equation of Muller (1979)): $I_{\text {geo }}=\log _{2}\left(C_{\mathrm{n}} / 1.5 B_{\mathrm{n}}\right)$, where $C_{\mathrm{n}}$ is the measured concentration in soil sample and $B_{\mathrm{n}}$ is the background concentration of the metals in soils worldwide (Kabata-Pendias and Pendias 2001). The classes of soils according to EF and $\mathrm{I}_{\text {geo }}$ are illustrated in Table 1.

The contaminated soils were subjected to sequential extraction method which was described previously by Tessier et al. (1979) and modified after by Phuong (2008); this method is based on the partitioning of particular metal traces of $1 \mathrm{~g}$ of soil which was 
attacked by $25 \mathrm{~mL}$ of $1 \mathrm{M} \mathrm{CH}_{3} \mathrm{COONH}_{4}$ at a pH of 7 in $50 \mathrm{~mL}$ centrifugation tubes in order to liberate exchangeable fractions; metals associated and bound to carbonate phases have been solubilized using $25 \mathrm{~mL}$ of $1 \mathrm{M} \mathrm{CH}_{3} \mathrm{COONa}$ adjusted to $5 \mathrm{pH}$ with $\mathrm{CH}_{3} \mathrm{COOH}$; the previous residue has been added to $25 \mathrm{~mL}$ of $30 \%$ $\mathrm{H}_{2} \mathrm{O}_{2}$ adjusted to $2 \mathrm{pH}$ with $\mathrm{HNO}_{3}$ which was added to liberate the metals associated with the bound to organic matter phases; the previous residue has been extracted with $25 \mathrm{~mL}$ of $0.2 \mathrm{M} \mathrm{NH}_{4}$-oxalate acidified $3.25 \mathrm{pH}$ with oxalic acid solution in order to release the metals associated with the bound to Fe-Mn oxide phases. Finally, the contaminants have been released by a mixture of strong acid $15 \mathrm{~mL}$ of $\mathrm{HCl}$ and $5 \mathrm{~mL}$ of concentrated $\mathrm{HNO}_{3}$. The extracts were analyzed by using atomic absorption spectrometer instrument (model: Perkin Elmer 400) in the National Research Centre laboratories in order to assess the metal $(\mathrm{Cd}, \mathrm{As}, \mathrm{Cr}, \mathrm{Pb}, \mathrm{Ni}$, and $\mathrm{Cu}$ ) concentrations.

The risk assessment code (RAC) was applied for evaluating the availability of metals in soils. According to Perin et al. (1985), RAC was calculated from the equation $\mathrm{RAC}=\left(100 \times F_{1}+F_{2}\right) /\left(F_{1}+F_{2}+F_{3}+F_{4}+F_{5}\right)$, where $F_{1}$ is the water-soluble and exchangeable fraction (Ex), $F_{2}$ is the carbonate-bound fraction $(\mathrm{Ct}), F_{3}$ is the organic matter-bound fraction $(\mathrm{Ob}), F_{4}$ is the Fe-Mn oxidebound fraction (FM), and $F_{5}$ is the residual fraction (Rd).

\section{Results}

The concentration range of $\mathrm{Cd}, \mathrm{As}, \mathrm{Cr}, \mathrm{Pb}, \mathrm{Ni}$, and $\mathrm{Cu}$ was $0.35-2.6$, bdl-140, 89-260, bdl-300, 18-170, and $35-140 \mathrm{ppm}$, respectively (Table 2). The obtained values of $\mathrm{EF}$ and $\mathrm{I}_{\text {geo }}$ were presented in Table 3. Cadmium fractionation data is recorded in Table 4 and demonstrated in Fig. 3. Carbonate fractions of As vary from 205 to $943 \mathrm{ppm}$ with an average 608.41 ppm in the selected sample soils (Table 5 and Fig. 4). Chromium, lead, nickel, and copper fractionation data is tabulated in Tables 6, 7, 8, and 9 and explained in Figs. 5, 6, 7, and 8. According to Perin et al. (1985), values of risk assessment code of heavy metals in the selected soils are listed in Table 10. The risk assessment

Table 6 Chromium fractionation results (ppm)

\begin{tabular}{llllll}
\hline Samples & Ex & $\mathrm{Ct}$ & $\mathrm{Ob}$ & $\mathrm{FM}$ & $\mathrm{Rd}$ \\
\hline $\mathrm{S}_{1}$ & $\mathrm{ND}$ & 77.62 & $\mathrm{ND}$ & $\mathrm{ND}$ & 75.38 \\
$\mathrm{~S}_{7}$ & $\mathrm{ND}$ & 76.45 & $\mathrm{ND}$ & $\mathrm{ND}$ & 103.55 \\
$\mathrm{~S}_{8}$ & $\mathrm{ND}$ & 52.08 & $\mathrm{ND}$ & $\mathrm{ND}$ & 136.92 \\
$\mathrm{~S}_{9}$ & $\mathrm{ND}$ & 86.13 & $\mathrm{ND}$ & $\mathrm{ND}$ & 84.87 \\
$\mathrm{~S}_{25}$ & $\mathrm{ND}$ & 114.67 & $\mathrm{ND}$ & $\mathrm{ND}$ & 74.33 \\
$\mathrm{~S}_{31}$ & $\mathrm{ND}$ & 95.33 & $\mathrm{ND}$ & $\mathrm{ND}$ & 75.67 \\
Mean & $\mathrm{ND}$ & 83.71 & $\mathrm{ND}$ & $\mathrm{ND}$ & 91.79 \\
\hline
\end{tabular}

Table $\mathbf{7}$ Lead fractionation results (ppm)

\begin{tabular}{llllll}
\hline Samples & Ex & $\mathrm{Ct}$ & $\mathrm{Ob}$ & $\mathrm{FM}$ & $\mathrm{Rd}$ \\
\hline $\mathrm{S}_{1}$ & 13.21 & 50.69 & 41.30 & 54.33 & 110.46 \\
$\mathrm{~S}_{7}$ & 5.58 & 12.41 & 19.32 & 23.29 & 38.39 \\
$\mathrm{~S}_{8}$ & 6.04 & 8.49 & 10.58 & 10.48 & 22.01 \\
$\mathrm{~S}_{9}$ & 8.12 & 15.26 & 11.42 & 13.08 & 23.22 \\
$\mathrm{~S}_{25}$ & 7.62 & 14.90 & 13.06 & 12.34 & 19.59 \\
$\mathrm{~S}_{31}$ & 6.51 & 11.32 & 10.05 & 9.18 & 15.14 \\
Mean & 7.85 & 18.85 & 17.62 & 20.45 & 38.13 \\
\hline
\end{tabular}

code had been classified into five categories according to Perin et al. (1985) as summarized in Table 11.

\section{Discussion}

The concentrations of $\mathrm{As}, \mathrm{Cr}$, and $\mathrm{Ni}$ exceed the maximum allowable concentration (MAC) set by Kabata-Pendias and Mukherjee (2007), while Cd, Pb, and $\mathrm{Cu}$ were within MAC. Based on the EF values, it is noticed that the samples which have a value exceeding 5 are considered rich in heavy metals according to the EF classification (Table 1). Also, the $\mathrm{I}_{\text {geo }}$ values of the studied samples which have a value over 2 represented polluted according to the EF classification (Table 1).

\section{Sequential extraction}

The most contaminated samples with $\mathrm{As}, \mathrm{Cr}, \mathrm{Pb}, \mathrm{Ni}$, and $\mathrm{Cu}$ are chosen based on the high enrichment factor and geoaccumulation index of these metals (Tables 1 and 3). The high contaminated samples are $\mathrm{S}_{1}, \mathrm{~S}_{7}, \mathrm{~S}_{8}, \mathrm{~S}_{9}, \mathrm{~S}_{25}$, and $S_{31}$. So, these samples were subjected to sequential extraction methods. The metal forms have been obtained from the sequential extraction schemes which will be discussed as the following:

\section{Cadmium}

Cadmium has no essential biological function, but it tends to accumulate in plants and aquatic biota with consequent problems of toxicity. It is toxic to humans through the inhalation of dust causing lung damage and

Table 8 Nickel fractionation results (ppm)

\begin{tabular}{llllll}
\hline Samples & Ex & $\mathrm{Ct}$ & $\mathrm{Ob}$ & $\mathrm{FM}$ & $\mathrm{Rd}$ \\
\hline $\mathrm{S}_{1}$ & 6.03 & 22.27 & 11.31 & 9.39 & 77.01 \\
$\mathrm{~S}_{7}$ & 5.65 & 18.47 & 13.61 & 9.20 & 79.08 \\
$\mathrm{~S}_{8}$ & 6.53 & 24.15 & 10.30 & 7.81 & 77.21 \\
$\mathrm{~S}_{9}$ & 6.72 & 26.27 & 9.63 & 7.76 & 84.62 \\
$\mathrm{~S}_{25}$ & 9.76 & 41.80 & 17.74 & 9.87 & 73.84 \\
$\mathrm{~S}_{31}$ & 8.97 & 31.77 & 14.93 & 8.24 & 62.08 \\
Mean & 7.28 & 27.45 & 12.92 & 8.71 & 75.64 \\
\hline
\end{tabular}


Table 9 Copper fractionation results (ppm)

\begin{tabular}{llllll}
\hline Samples & Ex & $\mathrm{Ct}$ & $\mathrm{Ob}$ & $\mathrm{FM}$ & $\mathrm{Rd}$ \\
\hline $\mathrm{S}_{1}$ & 2.71 & 6.72 & 16.54 & 33.49 & 57.55 \\
$\mathrm{~S}_{7}$ & 1.78 & 4.95 & 26.05 & 31.60 & 61.61 \\
$\mathrm{~S}_{8}$ & 2.40 & 3.78 & 23.35 & 33.65 & 62.83 \\
$\mathrm{~S}_{9}$ & 1.25 & 6.90 & 9.01 & 16.58 & 56.26 \\
$\mathrm{~S}_{25}$ & 1.64 & 9.72 & 14.77 & 14.64 & 49.23 \\
$\mathrm{~S}_{31}$ & 1.21 & 7.12 & 11.84 & 10.74 & 53.70 \\
Mean & 1.83 & 6.53 & 16.93 & 23.45 & 56.86 \\
\hline
\end{tabular}

may cause cancer from long-range exposure (WHO 1996). According to mean levels, the comparative mobility and bioavailability of $\mathrm{Cd}$ in the studied soils were decreased in the following order: $\mathrm{Ct}>\mathrm{Rd}>\mathrm{Ob}>$ FM $>$ Ex (Table 4 and Fig. 3). It is well known that $\mathrm{Cd}$ associated with the exchangeable fraction is really available, whereas that associated with both of carbonate, oxides, and organic matter is less available to biota. The residual fraction of $\mathrm{Cd}$ is actually unavailable to every plants or microorganism (Abollino et al. 2011; Wuana et al. 2012).

\section{Arsenic}

Anthropogenic activity has resulted in the widespread atmospheric deposition of arsenic from the burning of coal and the smelting of non-ferrous metals and phosphate fertilizers; the hazards resulting from geogenic load are generally regarded as lower than from anthropogenic contamination (Skala et al. 2011), and they clear that As is only associated with the non-residual carbonate fraction (Table 5 and Fig. 4), referring that As may be adsorbed, precipitated, or co-precipitated with carbonates (Smith and Naidu 2009). Then, the nonresidual carbonate fraction of As is potentially available to plants or microorganism.

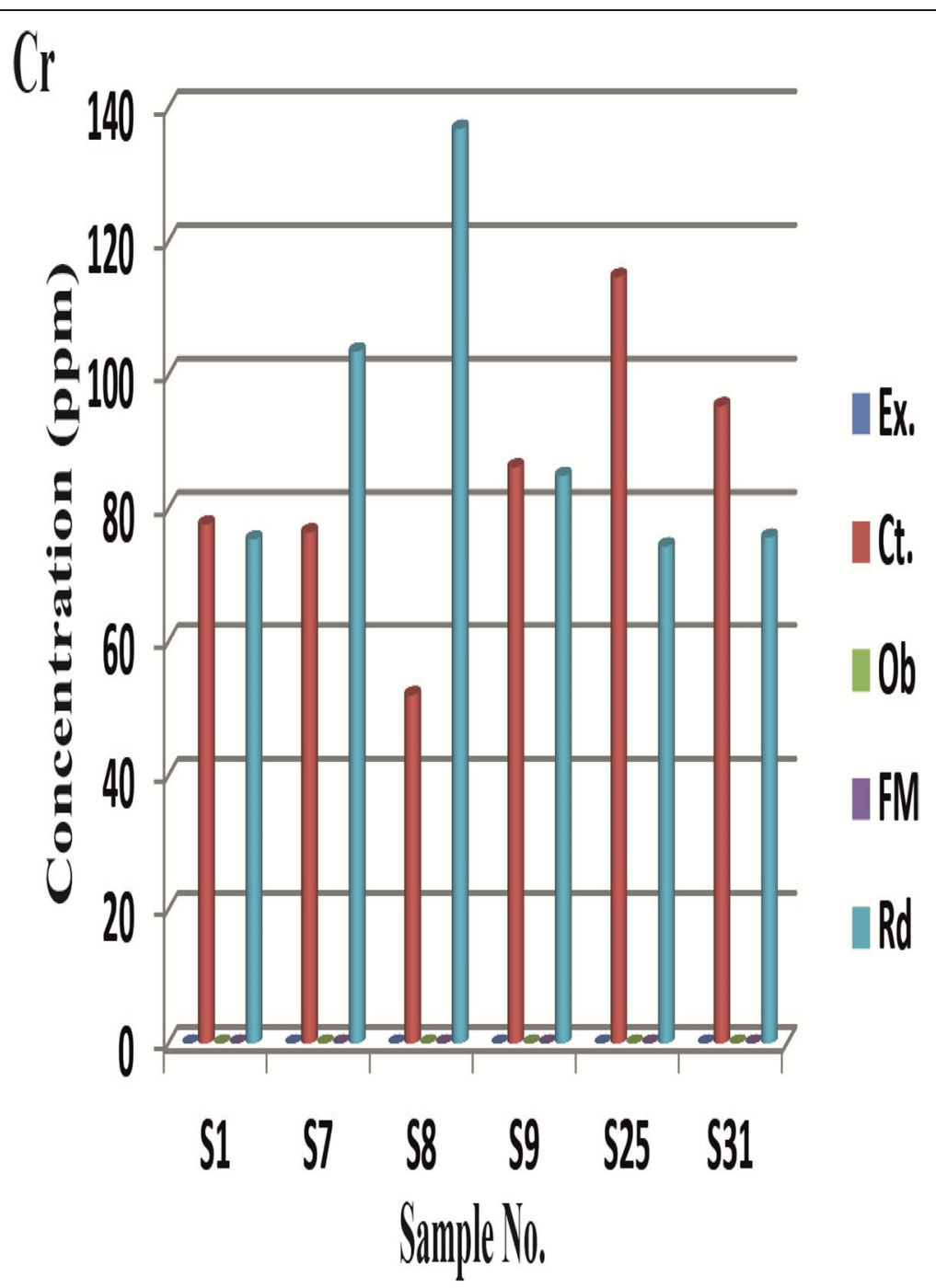

Fig. 5 Relative distribution of $\mathrm{Cr}$ among the various soil fractions in the study area 


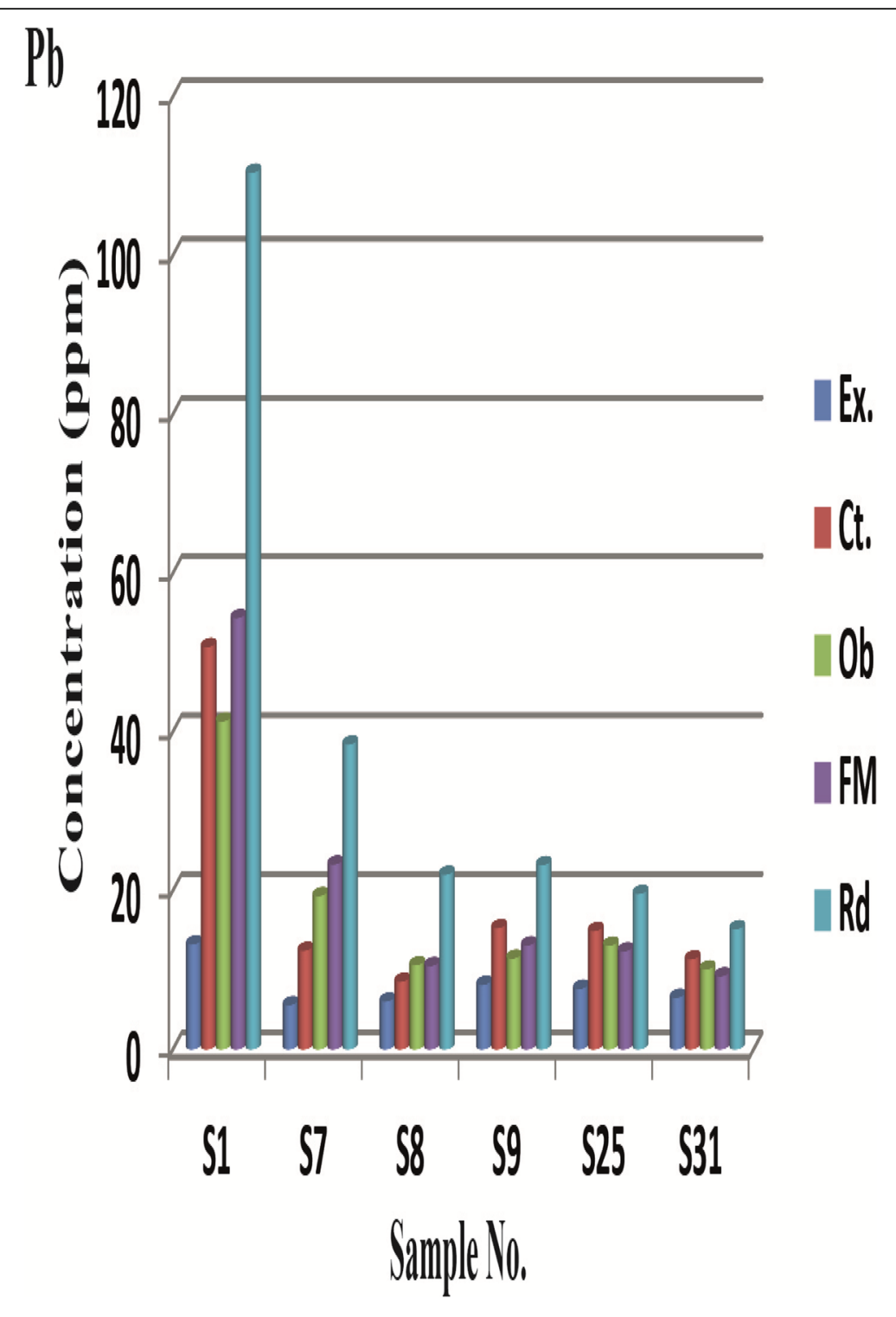

Fig. 6 Relative distribution of $\mathrm{Pb}$ among the various soil fractions in the study area

\section{Chromium}

The human body needed a small amount of $\mathrm{Cr}$ for insulin action and the metabolism of proteins and carbohydrates (Frausto da Silva and Williams 1991). Chromium has a varying toxicity depending on speciation in the environment. It is highly toxic, causing liver and kidney damage and acting as a carcinogen (WHO 1996). According to average values, the comparative mobility and bioavailability of $\mathrm{Cr}$ in the studied soil samples were decreased in the following order: $\mathrm{Rd}>\mathrm{Ct}$ (Table 6 and Fig. 5). This point to the authentic $\mathrm{Cr}$ was primarily concentrated in the clay minerals or incorporated in the lattice structure in the studied soils (Rao et al. 2007; Hseu 2006). Therefore, the nonresidual carbonate fraction of $\mathrm{Cr}$ is likely available to plants or microorganism. The residual fraction of $\mathrm{Cr}$ is actually unavailable to biota.

\section{Lead}

Lead has unknown biological role in plants or animals and is highly toxic to mammals and aquatic life; it can cause mental impairment in young children, causes neuropathy and hypertension in adults, and may be lethal at high levels, e.g., over $25 \mu \mathrm{g} \mathrm{kg}{ }^{-1}$ of body weight (WHO 1996). According to mean contents, the comparative mobility and bioavailability of $\mathrm{Pb}$ in the examined soil samples cleared a decrease in the following order: $\mathrm{Rd}>\mathrm{FM}>\mathrm{Ct}>\mathrm{Ob}>\mathrm{Ex}$ (Table 7 and Fig. 6). This indicates that the native $\mathrm{Pb}$ was mainly fixed in the lattice structure in the studied soils (Rao et al. 2007; 


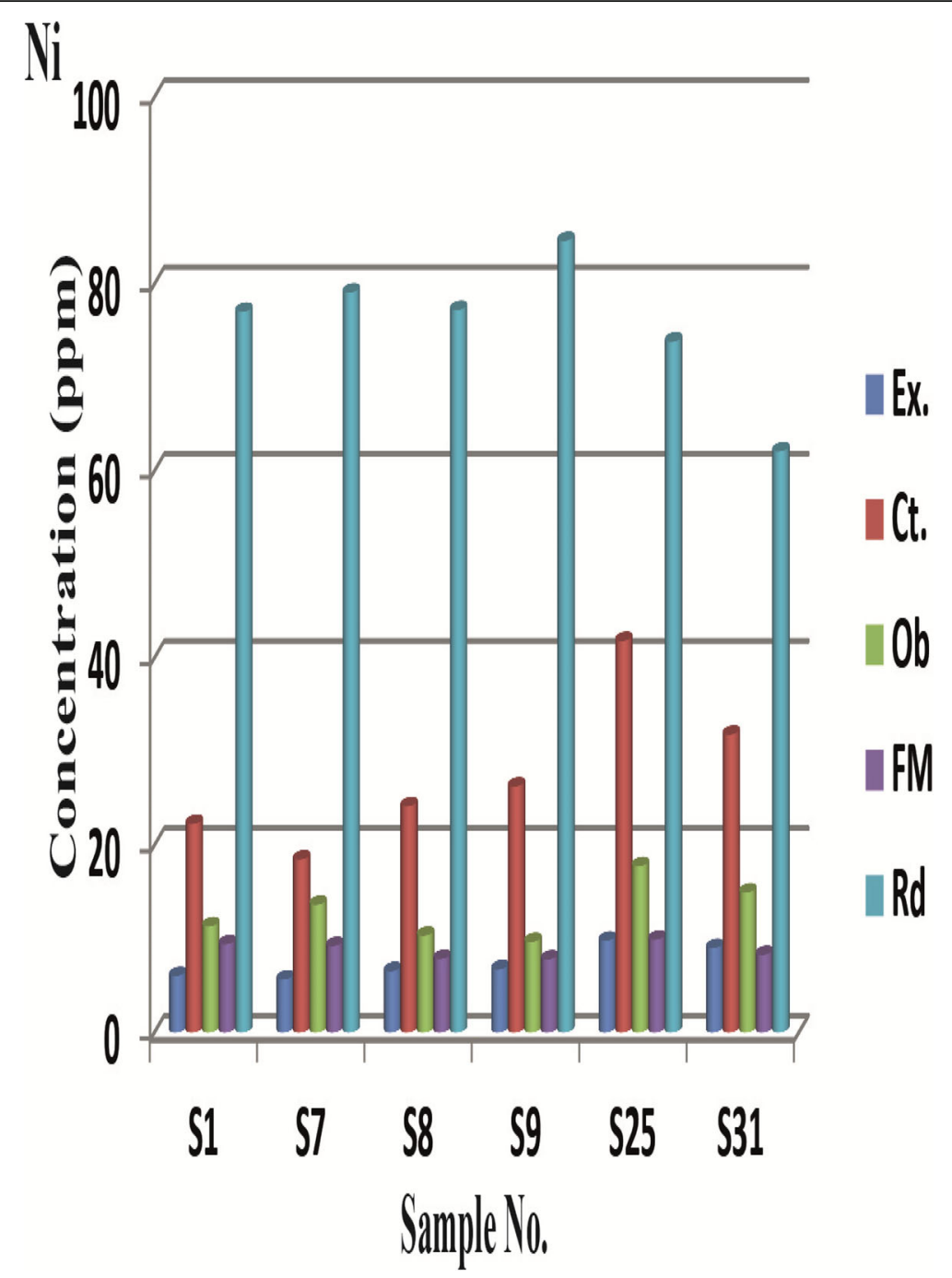

Fig. 7 Relative distribution of $\mathrm{Ni}$ among the various soil fractions in the study area

Hseu 2006; Sarkar et al. 2014). The residual fraction of $\mathrm{Pb}$ is indeed unavailable for biota.

\section{Nickel}

Nickel has been shown to be fundamental for microorganisms and having an essential role in human metabolism (McGrath 1995); most Ni compounds are comparatively non-toxic, but some compounds are highly toxic, and extreme excesses of $\mathrm{Ni}$ are both toxic, causing dermatitis and gastric irritation and carcinogenic illnesses (WHO 1996). According to average concentrations, the comparative mobility and bioavailability of $\mathrm{Ni}$ in the investigated soil samples were reduced in the following order: $\mathrm{Rd}>\mathrm{Ct}>\mathrm{Ob}>$ FM $>$ Ex (Table 8 and Fig. 7); this refers that the primary $\mathrm{Ni}$ was mostly concentrated in the clay fraction or may be incorporated in the lattice structure in the studied soils (Rao et al. 2007; Hseu 2006; Ayodele and Mohammed 2011). The total bulk of $\mathrm{Ni}$ in soil is really unavailable for biota.

\section{Copper}

Copper is an essential trace element for all organisms and humans which can bear levels up to $12 \mathrm{mg}$ per day, although the element can be toxic at extremely high levels (WHO 1996). Reimann and de Caritat (2005) report examples of kidney failure in small children resulting from drinking water polluted with copper in low $\mathrm{pH}$ environments containing high concentrations of $\mathrm{Cu}$ up to about $1 \mathrm{ppm}$. According to mean values, the comparative mobility and bioavailability of $\mathrm{Cu}$ in the studied soil samples were decrease in the following order: $\mathrm{Rd}>\mathrm{FM}>\mathrm{Ob}>\mathrm{Ct}>\mathrm{Ex}$ (Table 9 and Fig. 8). This refers that the authentic $\mathrm{Cu}$ was largely concentrated in the clay fraction of the studied soils or may be integrated in the lattice structures in soils (Rao et al. 2007; Hseu 2006; Rutkowska et al. 2013). The bulk of total $\mathrm{Cu}$ in soil is rightly unavailable to every plants and microorganism. 


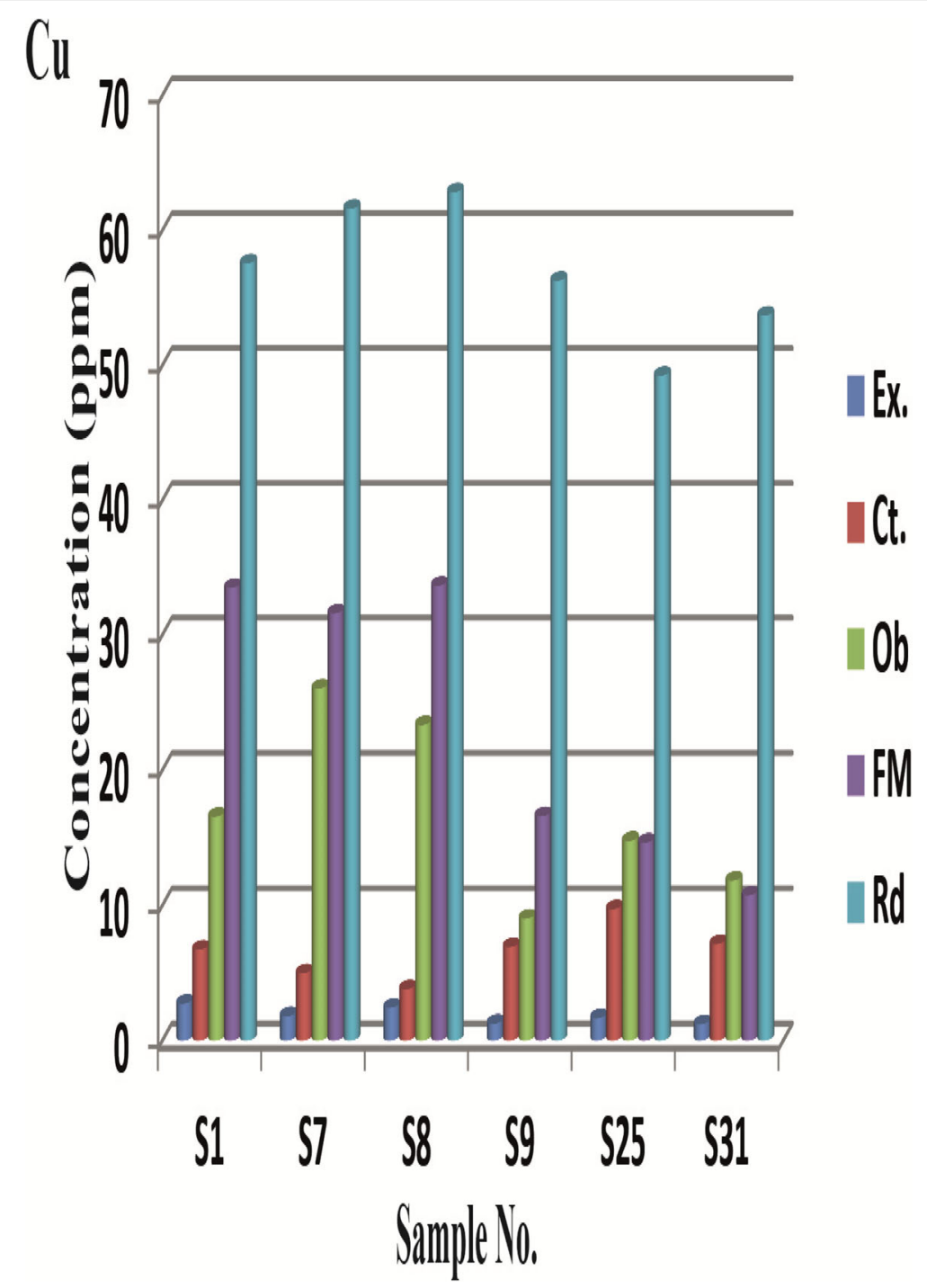

Fig. 8 Relative distribution of $\mathrm{Cu}$ among the various soil fractions in the study area

\section{Risk assessment code}

The risk assessment code (RAC) mainly compares the sum of the exchangeable and carbonate fractions with the total extracted for evaluating the availability of metals in soils. These fractions are considered to be

Table $\mathbf{1 0}$ Heavy metals risk assessment code (RAC\%) in selected soils

\begin{tabular}{lllllll}
\hline Samples & $\mathrm{Cd} \%$ & $\mathrm{As} \%$ & $\mathrm{Cr} \%$ & $\mathrm{~Pb} \%$ & $\mathrm{Ni} \%$ & $\mathrm{Cu} \%$ \\
\hline $\mathrm{S}_{1}$ & 67.21 & 100 & 50.73 & 23.67 & 22.46 & 8.05 \\
$\mathrm{~S}_{7}$ & 52.00 & 100 & 42.47 & 18.18 & 19.14 & 5.35 \\
$\mathrm{~S}_{8}$ & 42.86 & 100 & 27.56 & 25.23 & 24.35 & 4.90 \\
$\mathrm{~S}_{9}$ & 64.18 & 100 & 50.37 & 32.89 & 24.44 & 9.05 \\
$\mathrm{~S}_{25}$ & 69.64 & 100 & 60.67 & 33.35 & 33.70 & 12.62 \\
$\mathrm{~S}_{31}$ & 60.00 & 100 & 55.75 & 34.17 & 32.34 & 9.84 \\
Mean & 59.32 & 100 & 47.93 & 27.91 & 26.07 & 8.30 \\
\hline
\end{tabular}

Table 11 Classification of risk assessment code (RAC) in the studied soil

\begin{tabular}{|c|c|c|}
\hline Criteria & Risk & Samples \\
\hline$<1$ & No risk & - \\
\hline $1-10$ & Low risk & $S_{1}, S_{7}, S_{8}, S_{9}$, and $S_{31}$ in $C u \%$ \\
\hline \multirow[t]{4}{*}{$11-30$} & \multirow[t]{4}{*}{ Medium risk } & $\mathrm{S}_{8}$ in $\mathrm{Cr} \%$ \\
\hline & & $\mathrm{S}_{1}, \mathrm{~S}_{7}$, and $\mathrm{S}_{8}$ in $\mathrm{Pb} \%$ \\
\hline & & $\mathrm{S}_{1}, \mathrm{~S}_{7}, \mathrm{~S}_{8}$, and $\mathrm{S}_{9}$ in $\mathrm{Ni} \%$ \\
\hline & & $\mathrm{S}_{25}$ in $\mathrm{Cu} \%$ \\
\hline \multirow[t]{4}{*}{$31-50$} & \multirow[t]{4}{*}{ High risk } & $\mathrm{S}_{8}$ in $\mathrm{Cd} \%$ \\
\hline & & $\mathrm{S}_{7}$ in $\mathrm{Cr} \%$ \\
\hline & & $\mathrm{S}_{9}, \mathrm{~S}_{25}$, and $\mathrm{S}_{31}$ in $\mathrm{Pb} \%$ \\
\hline & & $\mathrm{S}_{25}$ and $\mathrm{S}_{31}$ in $\mathrm{Ni} \%$. \\
\hline \multirow[t]{3}{*}{$>50$} & \multirow[t]{3}{*}{ Very high risk } & All selected samples except $\mathrm{S}_{8}$ in $\mathrm{Cd} \%$. \\
\hline & & All selected samples in As\%. \\
\hline & & All selected samples in $\mathrm{Cr} \%$ except $\mathrm{S}_{7}$ and $\mathrm{S}_{8}$. \\
\hline
\end{tabular}


weakly bonded metals that may equilibrate with the aqueous phase and thus become more rapidly bioavailable (Singh et al. 2005; Li et al. 2011).

Tables 10 and 11 show that heavy metals are considered to be easily dissolved into the water by acidity (Perin et al. 1985; Jain 2004). The relative amounts of easily dissolved phase of heavy metals in the soils are in the order of $\mathrm{As}>\mathrm{Cd}>\mathrm{Cr}>\mathrm{Pb}>\mathrm{Ni}>\mathrm{Cu}$. According to RAC values, the risks of both of As, Cd, and $\mathrm{Cr}$ were very high. So, both $\mathrm{As}, \mathrm{Cd}$, and $\mathrm{Cr}$ should be recognized as priority pollutants in the soils of the study area.

\section{Conclusion}

The results indicated that the pollution with $\mathrm{As}, \mathrm{Cd}$, and $\mathrm{Cr}$ metals of some samples were the most of polluted samples according to the EF and $\mathrm{I}_{\text {geo }}$ and were subjected to sequential extraction, which indicated that $\mathrm{Cd}$ and As are mainly associated with carbonate fraction. On the other hand, $\mathrm{Pb}, \mathrm{Cr}, \mathrm{Ni}$, and $\mathrm{Cu}$ are mainly incorporated in the residual fraction, and calculated RAC cleared the potential availabilities of As, $\mathrm{Cd}$, and $\mathrm{Cr}$ in the study area.

\section{Acknowledgements}

The National Research Centre is the organization that funded this research as a Ph.D. internal project, and the grant number is (8/5/9) to support Mr. Ahmed A. Asmoay to do the lab work.

\section{Authors' contributions}

All authors contributed equally in the all article steps. All authors read and approved the final manuscript.

\section{Authors' information}

Not applicable

\section{Funding}

Not applicable

\section{Availability of data and materials \\ Not applicable}

\section{Ethics approval and consent to participate}

Accepted

\section{Consent for publication}

Accepted

\section{Competing interests}

The authors declare that they have no competing interests.

\section{Author details}

${ }^{1}$ Geological Sciences Department, National Research Centre, 33 El Bohouth St. (former El Tahrir St.)-Dokki, Giza 12622, Egypt. ${ }^{2}$ Geology Department, Faculty of Science, Al Azhar University, Cairo, Egypt.

Received: 27 November 2018 Accepted: 15 May 2019

Published online: 06 June 2019

\section{References}

Abd Elsanad EEY (2010) Geophysics and hydrogeological studies for evaluation the groundwater potentiality in the reclaimed area, west Minia District, Egypt. M. Sc. Thesis, Geol. Dep., Facaluty of Scince, Minia univ., Egypt
Abollino O, Malandrino M, Giacomino A, Mentasti E (2011) The role of chemometrics in single and sequential extraction assays: a review. Anal Chim Acta 688:104-121

Aiju L, Yanchun G, Honghai W, Gao Peiling G (2012) An assessment of heavy metals contamination in Xiaofu River sediments through chemical speciation study. Int J Earth Sci 5(5):1235-1240

Ayodele JT, Mohammed SS (2011) Speciation of nickel in soils and cereal. Res J Appl Sci Eng Technol 3(3):202-209

Buat-Menerd P, Chesselt R (1979) Variable influence of the atmospheric flux on the trace metal chemistry of oceanic suspended matter. Earth Planet Sci Lett 42:398-411

Buccolieri A, Buccolieri G, Dell'Atti A, Strisciullo G, Gagliano-Candela R (2010) Monitoring of total and bioavailable heavy metals concentration in agricultural soils. Environ Monitor Assess 168(1-4):547-560

Covelo EF, Vega FA, Andrade ML (2007) Simultaneous sorption and desorption of $\mathrm{Cd}, \mathrm{Cr}, \mathrm{Cu}, \mathrm{Ni}, \mathrm{Pb}$ and $\mathrm{Zn}$ in acid soils II: soil ranking and influence of soil characteristics. J Hazard Mater 147:862-870

Davutluoglu OI, Seckin G, Ersu CB, Yilmaz T, Sari B (2011) Heavy metal content and distribution in surface sediments of the Seyhan River, Turkey. J Environ Manag 92:2250-2259

Elnazer A, Salman A, Seleem M, Abu El Ella E (2015) Assessment of some heavy metals pollution and bioavailability in roadside soil of Alexandria-Marsa Matruh highway. Egypt Int J Ecol 689420:7p

Frausto da Silva JTR, Williams RJP (1991) The biological chemistry of the elements: the inorganic chemistry of life. Clarendon Press, Oxford, p 561

Ghaderi AA, Abduli MA, Karbassi AR, Nasrabadi T, Khajeh M (2012) Evaluating the effects of fertilizers on bioavailable metallic pollution of soils, case study of Sistan farms. Iran Int J Environ Res 6(2):565-570

Gupta AK, Sinha S (2006) Role of Brassica juncea (L.) Czern. (var. Vaibhav) in the phytoextraction of Ni from soil amended with fly ash: selection of extractant for metal bioavailability. J Hazard Mater B136:371-378

Hseu ZY (2006) Extractability and bioavailability of zinc over time in three tropical soils incubated with biosolids. Chemosphere 63:762-771

Jain CK (2004) Metal fractionation study on bed sediments of River Yamuna, India. J. Water Res 38:569-578

Kabata-Pendias A, Mukherjee AB (2007) Trace elements from soil to human. Springer, Berlin Heidelberg New York, p 550

Kabata-Pendias A, Pendias H (2001) Trace elements in soils and plants. CRC Press, Boca Raton

Kierczak J, Neel C, Aleksander-Kwaterczak U, Helios-Rybicka E, Bril H, Puziewicz J (2008) Solid speciation and mobility of potentially toxic elements from natural and contaminated soils: a combined approach. Chemosphere. 73:776-784

Lee CSL, Li XD, Zhang G, Li J, Ding AJ, Wang T (2007) Heavy metals and Pb isotopic composition of aerosols in urban and suburban areas of Hong Kong and Guangzhou, South China - evidence of the long-range transport of air contaminants. Atmos Environ 41:432-447

Li R, Yang H, Zhou Z, Lu J, Shao X, Jin F (2011) Fractionation of heavy metals in sediments from Dianchi lake, China. J. Pedosphere 17(2):265-272

Maas S, Scheifler R, Benslama M, Crini N, Lucot E, Brahmia Z, Benyacoub S, Giraudoux P (2010) Spatial distribution of heavy metal concentrations in urban, suburban and agricultural soils in a Mediterranean city of Algeria. Environ Pollut 158:2294-2301

McGrath SP (1995) Nickel. In: Alloway BJ (ed) Heavy metals in soils. Blackie Academic \& Professional, London

Mohamed WS, Ismail EA, Zaki R, Kamel A (2015) Regional assessment of heavy metals pollution in irrigated soils, west El Minia district, Egypt. Egypt J of Geol 59:101-112

Muller G (1979) Index of geoaccumulation in sediments of the Rhine River. Geol J 2:109-118

Nemati K, Abu Bakar NK, Radzi Abas M, Sobhanzadeh E (2011) Speciation of heavy metals by modified BCR sequential extraction procedure in different depths of sediments from Sungai Buloh, Selangor, Malaysia. J Hazard Mater 192(1):402-410

Perez-Lopez R, Niet JM, Lopez-Coto I, Aguado JL, Bolivar JP, Santisteban M (2010) Dynamics of contaminants in phosphogypsum of the fertilizer industry of Huelva (SW Spain): from phosphate rock ore to the environment. Appl Geochem 25:705-715

Perin G, Craboledda L, Lucchese M, Cirillo R, Dotta L, Zanette ML, Orio AA (1985) Heavy metal speciation in the sediments of northern Adriatic Sea- a new approach for environmental toxicity determination. In: Lekkas TD (ed) Heavy Metal in the Environment, vol 2, pp 454-456 
Phuong NK (2008) Geochemical study of arsenic behavior in aquifer of the Mekong Delta, Vietnam, Ph.D. Thesis, Graduate School of Engineering, Kyushu Univ

Rao CRM, Sahuquillo A, Lopez Sanchez JJ (2007) A review of the different methods applied in environmental geochemistry for single and sequential extraction of trace elements in soils and related materials. Water Air Soil Pollution 189:291-333

Rao CRM, Sahuquillo A, Lopez-Sanchez JF (2010) Comparison of single and sequential extraction procedures for the study of rare earth elements remobilisation in different types of soils. Anal Chim Acta 662(2):128-136

Rauret G, Lopez-Sanchez JF, Sahuquillo A, Rubio R, Davidson C, Ure A, Quevauviller P (1999) Improvement of the BCR three step sequential extraction procedure prior to the certification of new sediment and soil reference materials. J Environ Monit 1:57-61

Reimann C, de Caritat P (2005) Distinguishing between natural and anthropogenic sources for elements in the environment: regional geochemical surveys versus enrichment factors. Sci Total Environ 337:91-107

Rutkowska B, Szulc W, Bomze K (2013) Effects of soil properties on copper speciation in soil solution. J Elem Sci:695-703

Said I, Salman A, Samy Y, Awad S, Melegy A (2019) Environmental factors controlling potentially toxic element behaviour in urban soils, El Tebbin, Egypt. Environ Monit Assess 191:267

Said R (1981) The geological evolution of the River Nile. Springer Verlag, New York, Berlin, p 151

Salman A, Elnazer A, Abu El Ella E (2018) Sequential extraction of some heavy metals in Southwest Giza soil, Egypt. Egypt J Chem 61(5):785-797

Salman A, Elnazer A, El Nazer H (2016) Integrated mass balance of some heavy metals fluxes in Yaakob village, south Sohag, Egypt. Inter J Environ Sci. https://doi.org/10.1007/s13762-016-1200-3

Sarkar SK, Favas PJC, Rakshit, D, Satpathy KK. Geochemical speciation and risk assessment of heavymetals in soils and sediments. In: HernandezSoriano, M.C. (Ed.), Environmental Risk Assessment of Soil Contamination. InTech. 2014: 918 p

Singh KP, Mohan D, Singh VK, Malik A (2005) Studies on distribution and fractionation of heavy metals in Gomti river sediments- a tributary of the Ganges, India. J Hydrol 312:14-27

Skala J, Vacha R, Jarmila CJ (2011) Evaluation of arsenic occurrence in agricultural soils of the Bohemian Forest region. Research Institute for Soil and Water Conservation, Silva Gabreta, Vimperk. 17(2-3):55-67

Smith E, Naidu R (2009) Chemistry of inorganic arsenic in soils: kinetics of arsenic adsorption-desorption. Environ Geochem Health 31:49-59

Tessier A, Campbell PGC, Blsson M (1979) Sequential extraction procedure for the speciation of particulate trace metals. Anal Chem 51:844-851

Vega FA, Covelo EF, Andrade ML, Marcet P (2004) Relationship between heavy metals content and soil properties in mine soils. Analytical Chem Acta 524: $141-150$

Wali A, Coinet G, Khadhraoui M, Ksibi M (2013) Trace metals in surface soil contamination by release of phosphate industry in the surroundings of SfaxTunisia. Environ Res Eng Manag 65(3):20-30

WHO (1996) Biological monitoring of chemical exposure in the workplace. World Health Organ Geneva 1:294

Wuana RA, Adie PA, Asegh IN (2012) Seasonal variation in bioavailability of some toxic metals in waste dump soils of Makurdi, North-Central Nigeria. J Biodiv Environ Sci 2(11):7-17

Yang Y, Chen F, Zhang L, Liua J, Wu S, Kang M (2012) Comprehensive assessment of heavy metal contamination in sediment of the Pearl River Estuary and adjacent shelf. Mar Pollut Bull 64:1947-1955

Zemberyova M, Bartekova J, Hagarova I (2006) The utilization of modified BCR threestep sequential extraction procedure for the fractionation of $\mathrm{Cd}, \mathrm{Cr}, \mathrm{Cu}, \mathrm{Ni}, \mathrm{Pb}$ and $\mathrm{Zn}$ in soil reference materials of different origins. Talanta. 70:973-978

\section{Publisher's Note}

Springer Nature remains neutral with regard to jurisdictional claims in published maps and institutional affiliations.

\section{Submit your manuscript to a SpringerOpen ${ }^{\circ}$ journal and benefit from:}

- Convenient online submission

- Rigorous peer review

- Open access: articles freely available online

- High visibility within the field

- Retaining the copyright to your article

Submit your next manuscript at $\boldsymbol{\nabla}$ springeropen.com 